\title{
Sokeri- ja valkuaislisä korkeatuottoisten lypsylehmien väkirehussa nurmisäilörehuruokinnalla
}

\author{
Juha Seppälä, Esko Poutiainen ja Pärvi Luoma \\ Helsingin yliopiston kotieläintieteen laitos, 00710 Helsinki 71
}

\section{Administration of sugar and protein supplements in concentrates to high ylelding dairy cows fed on grass silage}

Juha Seppälä, Esko Poutrainen and Pärvi Luoma

Department of Animal Husbandry, University of Helsinki, 00710 Helsinki 71

\begin{abstract}
A feeding experiment was performed with high yielding dairy cows in order to study the effect of dried molassed beet pulp and soya bean meal supplied in concentrates.

Hay was given at the rate of $2 \mathrm{~kg}$ DM for groups I (S) and II (SM) and at 4 kg DM for group III (SS) with grass silage ad lib. For group I (S) the concentrate was a barley-oat mixture. The concentrate for group II (SM) was supplemented with $20 \%$ of dried molassed beet pulp and for group III (S) with $11 \%$ soya bean meal.

The average milk yield during the experiment $(0-9$ weeks post parturition) for group I (S) was $21.7 \pm 4.5$, for group II (SM) $24.4 \pm 5.1$ and for group III (SS) $24.6 \pm 6.5 \mathrm{~kg}$ FCM per day. Differences between the groups were not significant.

During the first 9 weeks after calving, feed energy provided $94 \%$ of the calculated energy requirement of group I (S), $82 \%$ of group II (SM) and $90 \%$ of group III (SS). The intake of digestible crude protein exceeded the standard in all groups.

The calcium intake after calving provided $70-82 \%$ of the calcium requirement. The intake of magnesium was $64-90 \%$ of the magnesium requirement. The supply of other minerals exceeded the standards in all groups.

No differences between groups were detected in contents of haemoglobin, glucose or blood ketones. The inorganic phosphorus content of the plasm of group II (SM) was higher $(\mathrm{P}<0.01)$ and the calcium content lower $(\mathrm{P}<0.05)$ than the corresponding content of groups I (S) and III (SS).
\end{abstract}

\section{Johdanto}

Laajat kotimaiset ruokintatutkimukset ovat osoittaneet, että lypsylehmien ravinnontarve pystytään tyydyttämään korkealaatuisella nurmisäilörehulla ja kotoisella viljaväkirehulla (ETTALA ym. 1976). Tutkimukset on suoritettu pääasiassa tuotantokauden keskivaiheessa olevilla lehmillä. 
Laktaatiokauden alun ruokintaa on vaikeinta tasapainoittaa vastaamaan lypsylehmän ravinnontarvetta. Säilörehuruokinnan yhteydessä on syytä selvittää, pystytäänkö runsaalla nurmisäilörehun käytöllä tyydyttämään lypsylehmien ravinnontarve myös korkeimman tuotannon vaiheessa. Säilönnän yhteydessä osa raaka-aineen valkuaisesta hajoaa yksinkertaisiksi typellisiksi yhdisteiksi. Sokerit käyvät orgaanisiksi hapoiksi ja puristemehun mukana poistuu arvokkaita ravintoaineita. Haitallisten muutosten määrä riippuu raaka-aineen vesipitoisuudesta ja säilönnän onnistumisesta.

Pötsikäymisessä muodostuva mikrobivalkuainen ei riitä tyydyttämään runsastuottoisen lehmän aminohappotarvetta (KAUfMann ja HAGEMEISTER1975). Hyvälaatuista, etumahat ohittavaa rehuvalkuaista tarvitaan sitä enemmän mitä korkeampi on tuotantotaso. Rehuyhdistelmän energia- ja hiilihydraattikoostumus vaikuttaa mikrobivalkuaisen muodostukseen.

Ruokintakokeet ovat osoittaneet, että hyvälaatuisella rehuvalkuaisella saadaan tuotoslisää normit ylittävällä valkuaisruokinnalla silloin kun pääosa valkuaisesta on peräisin nurmisäilörehusta (Mo ym. 1974, CASTLE ja WATSON 1974). Helppoliukoisten hiilihydraattien, erikoisesti sokerin on osoitettu parantavan nurmisäilörehun typellisten aineiden hyväksikäyttöä märehtijällä (SYRJÄLÄ 1972), varsinkin säilörehun ollessa runsaasti käynyttä (SYRJÄLÄ 1975).

Tämän tutkimuksen tarkoituksena oli selvittää melassileike- ja soijalisän vaikutusta rehunkulutukseen, maitotuotokseen sekä eräisiin veriarvoihin tunnutus-, poikimis- ja herutusvaiheessa lehmillä, jotka ovat säilörehuruokinnalla.

\section{Aineisto ja menetelmät}

Tutkimus suoritettiin Viikin opetus- ja koetilalla kevättalvella 1973 ryhmäkokeena, missä kukin lehmä oli yksilöruokinnalla. Kokeessa oli kolme ruokintaryhmää. Ryhmiin II (SM) ja III (SS) kuului 6 ay-rotuista lehmää, kun ryhmässä I (S) oli sairastumisten vuoksi $5 \mathrm{kpl}$. Kussakin ryhmässä oli 2 kpl ensikkoa, $2 \mathrm{kpl}$ toista lypsykauttaan lypsävää sekä $2 \mathrm{kpl}$ kolmatta tai useampaa lypsykauttaan lypsävää lehmää. Valintaperusteina ryhmiin jaossa käytettiin elopainoa ja edellisen vuoden tietoja 4-\% maitotuotoksesta ja laktaatiohuipusta.

Koe alkoi 2 viikkoa ennen laskettua poikimispäivää ja jatkui 9 viikkoa poikimisen jälkeen.

\section{Rehut ja ruokinta}

Perusrehuina olivat nurmisäilörehu ja heinä. Heinäannos oli ryhmillä I (S) ja II (SM) 2.0 kg heinän kuiva-ainetta ja ryhmällä III (SS) $4.0 \mathrm{~kg}$. Säilörehuannos oli koesuunnitelman mukaan ryhmillä I (S) ja II (SM) 8 kg säilörehun kuiva-ainetta ja ryhmällä III (SS) 6 kg. Käytännössä alhaisen säilörehun syönnin vuoksi koelehmät saivat nurmisäilörehua ad lib.

Väkirehuna ryhmä I (S) sai pelkkää kaura-ohrajauhoseosta $(50: 50)$, ryhmä II (SM) sai sokerilisänä kuivattua melassileikettä $20 \%$ väkirehussa ja ryhmä III (SM) valkuaislisänä $11 \%$ soijarouhetta. 
Väkirehuannos ennen poikimista oli ryhmillä I (S) ja II (SM) 3 kg sekä ryhmällä III (SS) $3.4 \mathrm{~kg}$. Väkirehuannosta lisättiin poikimisen jälkeen kolmannesta päivästä lähtien $0.5 \mathrm{~kg}$ joka toinen päivä maitotuotoksen mukaan.

Kivennäisrehuna käytettiin fosforipitoista kivennäisseosta Fosfori-Lypsyä, mikä sisälsi Ca $10.5 \%$, P $11.8 \%$ sekä Mg $1.5 \%$. Kivennäisrehuannostus oli $10 \mathrm{~g} /$ maitokg, kuitenkin vähintäin $200 \mathrm{~g} / \mathrm{pv}$. Na-tarpeen tyydyttämiseksi lisättiin lypsäville lehmille väkirehussa ruokasuolaa $50 \mathrm{~g} / \mathrm{pv}$.

Lehmien ruokintanormeina käytettiin tuotantorehun osalta 0.4 ry ja $60 \mathrm{~g}$ srv per 4-\%:inen maitokilo. Ylläpitonormina $500 \mathrm{~kg}$ painavalle lehmälle laskettiin 3.8 ry ja $320 \mathrm{~g}$ srv per päivä. Kivennäistarpeen laskemisessa käytettiin ARC:n (ANon. 1965) normeja.

Taulukko 1. Koerehujen keskimääräinen kemiallinen koostumus.

Table 1. Mean chemical composition of the feeds.

\begin{tabular}{|c|c|c|c|c|c|c|}
\hline & & \multirow{2}{*}{$\begin{array}{l}\text { Nurmisäilö- } \\
\text { rehu } \\
\text { Grass silage }\end{array}$} & \multirow[t]{2}{*}{$\begin{array}{c}\text { Heinä } \\
\text { Hay }\end{array}$} & \multicolumn{3}{|c|}{$\begin{array}{c}\text { Väkirehuseos } \\
\text { Concentrate mixture }\end{array}$} \\
\hline & & & & I (S) & II (SM) & III (SS) \\
\hline $\begin{array}{l}\text { ka \% } \\
\text { DM \% }\end{array}$ & & 32.1 & 85.3 & 90.1 & 89.1 & 90.2 \\
\hline \multirow[t]{3}{*}{$\begin{array}{l}\% \text { kuiva-aineessa } \\
\% \text { in } D M\end{array}$} & $\begin{array}{l}\text { Raakakuitu } \\
C F\end{array}$ & 26.3 & 32.9 & 7.4 & 8.6 & 8.1 \\
\hline & $\begin{array}{l}\text { Raakavalk. } \\
C P\end{array}$ & 22.5 & 12.1 & 14.5 & 14.4 & 18.5 \\
\hline & $\begin{array}{l}\text { Sokerit } \\
\text { Sugars }\end{array}$ & 1.4 & 5.0 & 2.0 & 6.7 & 2.9 \\
\hline rehuyksikōssä & $\begin{array}{l}\text { kg ka } \\
\text { kg } D M\end{array}$ & 1.32 & 1.87 & 0.91 & 0.92 & 0.91 \\
\hline in feed unit & $\begin{array}{l}g \text { srv } \\
g \text { DCP }\end{array}$ & 215 & 126 & 100 & 98 & 131 \\
\hline $\mathrm{g} / \mathrm{kg} \mathrm{ka}$ & $\mathrm{Ca}$ & 4.9 & 2.4 & 0.8 & 2.0 & 1.3 \\
\hline $\mathrm{g} / \mathrm{kg} \mathrm{DM}$ & $\begin{array}{l}\mathrm{P} \\
\mathrm{Mg}\end{array}$ & $\begin{array}{l}3.4 \\
1.0\end{array}$ & $\begin{array}{l}2.8 \\
0.6\end{array}$ & $\begin{array}{l}3.7 \\
1.0\end{array}$ & $\begin{array}{l}3.1 \\
1.5\end{array}$ & $\begin{array}{l}4.0 \\
1.2\end{array}$ \\
\hline $\begin{array}{l}\% \text { tuoreessa } \\
\text { rehussa }(20 \% \mathrm{ka}) \\
\% \text { in fresh silage }\end{array}$ & $\begin{array}{l}\mathrm{pH} \\
\text { Maitohappo } \\
\text { Lactid acid }\end{array}$ & $\begin{array}{r}4.3 \\
1.15\end{array}$ & $\begin{array}{l}- \\
-\end{array}$ & - & - & $\begin{array}{l}- \\
-\end{array}$ \\
\hline \multirow[t]{2}{*}{$(20 \% D M)$} & $\begin{array}{l}\text { Etikkahappo } \\
\text { Acetic acid }\end{array}$ & 0.66 & - & - & - & - \\
\hline & $\begin{array}{l}\text { Voihappo } \\
\text { Butyric acid }\end{array}$ & 0.04 & - & - & - & - \\
\hline $\begin{array}{l}\% \text { kok. } \mathrm{N} \\
\% \text { in total } \mathrm{N}\end{array}$ & $\begin{array}{l}\mathrm{NH}_{3}-\mathrm{N} \\
\text { Liukoinen } \mathrm{N} \\
\text { Soluble } N\end{array}$ & $\begin{array}{l}13.3 \\
67\end{array}$ & - & - & - & - \\
\hline
\end{tabular}




\section{Näytteiden otto ja kemialliset analyysit}

Säilörehunäyte otettiin tornista kerran kahdessa viikossa niin, että se edusti vastaavana aikana kulutettua rehumäärää. Heinä- ja väkirehunäytteet otettiin päivittäin ja koottiin edustamaan neljän viikon näyte-erää. Kaikista rehynäytteistä tehtiin virallinen rehuanalyysi standardimenetelmien mukaan. Samoin määritettiin pelkistävät sokerit SALOn (1965) menetelmällä. Rehujen kivennäispitoisuudet määritettiin atomiabsortiomenetelmällä, lukuunottamatta fosforia, mikä määritettiin molybdeenisinimenetelmällä. Säilörehusta määritettiin lisäksi $\mathrm{pH}$, haihtuvat rasvahapot kaasukromatograafisesti Kotieläinhoidon tutkimuslaitoksella (Huida 1973), maitohappo (BARKer ja Summerson 1941), $\mathrm{NH}_{3}-\mathrm{N}$ (McGullough 1967), sekä liukoinen typpi. Koerehujen kemiallinen koostumus on esitetty taulukossa 1 .

Käytetty nurmisäilörehu sisälsi $\mathrm{NH}_{3}-\mathrm{N}$ keskimäärin $13.3 \%$ kokonaistypestä, mikä ylittää hyvälaatuisen säilörehun rajana pidetyn $8 \%$. Voihappoa esiintyi vain kahdessa näytteessä kymmenestä. Alhainen sokeripitoisuus osoittaa säilörehussa tapahtuneen voimakasta käymistä lievästä esikuivatuksesta huolimatta (taulukko 1).

Maitotuotos punnittiin joka lypsykerta. Maitonäytteet otettiin kerran viikossa kahtena perättäisenä päivänä. Maidon rasvapitoisuus analysoitiin Gerberin menetelmällä ja valkuaispitoisuus Prot-O-Mat laitteella.

Verinäytteet otettiin jokaiselta lehmältä kahden viikon välein aamuruokinnan jälkeen. Verestä määritettiin hemoglobiini, hematokriitti, glukoosi NELSoNin (1944) ja Somogyin (1945) menetelmällä, ketoaineet BAKкERin ja WhiтEn (1957) menetelmällä. Plasman kivennäisaineet määritettiin atomiabsorptiomenetelmällä lukuunottamatta epäorgaanista fosforia, mikä määritettiin TAUSSKYn ja SHORRin (1953) menetelmällä.

\section{Tulokset}

Rehunkulutus ja maitotuotos. Kuiva-aineen syönti ennen poikimista oli keskimäärin $1.5 \pm 0.3 \mathrm{~kg} \mathrm{ka} / 100$ elopainokg. Ryhmän I (S) lehmät söivät ennen poikimista merkitsevästi $(\mathrm{P}<0.05)$ enemmän kuin ryhmän II (SM) lehmät $(1.8 \pm 0.2$ ja $1.3 \pm 0.3)$.

Rehuannoksen kuiva-aineen syönti lisääntyi voimakkaimmin ensimmäisen kuukauden aikana poikimisesta keskimäärin $40 \mathrm{~g}$ ka/100 elopainokg päivässä (kuva 1). Väkirehulisäys oli $250 \mathrm{~g} / \mathrm{pv}$. Rehun syönti oli korkeimmillaan kokeen lopussa 6-9 viikkoa poikimisesta. Ryhmittäiset keskiarvot olivat tällöin ryhmillä I (S), II (SM) ja III (SS) $2.8 \pm 0.1,3.0 \pm 0.2$ ja $3.0 \pm 0.4 \mathrm{~kg} \mathrm{ka} / 100$ elop.kg tässä järjestyksessä. Erot eivät olleet merkitseviä. Keskimäräinen rehunkulutus on esitetty taulukossa 2 .

Lehmät eivät syöneet koesuunnitelman mukaisia määriä nurmisäilörehua. Ryhmän I (S) lehmät söivät kokeen aikana keskimäärin $4.8 \pm 1.3 \mathrm{~kg}$ ja ryhmän II (SM) $4.5 \pm 1.4 \mathrm{~kg}$ säilörehun kuiva-ainetta. Ryhmän III (SS) lehmät söivät säilörehua $4.5 \pm 1.1 \mathrm{~kg}$ ka. Väkirehuannckset olivat suurimmillaan ryhmällä I (S) $6.3 \pm 0.6 \mathrm{~kg}$ ka, ryhmällä II (SM) $6.7 \pm 1.6 \mathrm{~kg}$ sekä ryhmällä III (SS) $7.1 \pm 1.2 \mathrm{~kg}$ väkirehuseoksen kuiva-ainetta. Väkirehun osuus kuiva-aineen 
Taulukko 2. Ryhmien keskimääräinen rehunkulutus (kg ka/eläin) päivässä.

Table 2. The mean daily feed consumption of the groups (kg DM/cow).

\begin{tabular}{|c|c|c|c|}
\hline & $\begin{array}{l}\text { R y h m : } \\
\text { I (S) }\end{array}$ & $\begin{array}{l}\text { Group } \\
\text { II (SM) }\end{array}$ & III (SS) \\
\hline 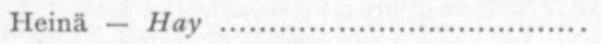 & $1.5^{b} \pm 0.3$ & $1.6^{b} \pm 0.3$ & $2.1^{\mathrm{a}} \pm 0.6$ \\
\hline Säilörehu - Grass silage ......................... & $4.8 \pm 1.3$ & $4.5 \pm 1.4$ & $4.5 \pm 1.1$ \\
\hline Väkirehu - Concentrate .......................... & $5.0 \pm 1.6$ & $5.0 \pm 2.1$ & $5.5 \pm 2.1$ \\
\hline $\begin{array}{l}\text { Kokonaisrehunkulutus }- \text { Total feed } \\
\text { consumption }\end{array}$ & $11.3 \pm 2.3$ & $11.1 \pm 3.2$ & $12.1 \pm 3.3$ \\
\hline
\end{tabular}

Merkitsevät erot ruokintaryhmien välillä

$\mathrm{a}-\mathrm{b}: \mathrm{P}<0.05$

Significant differences between feeding groups

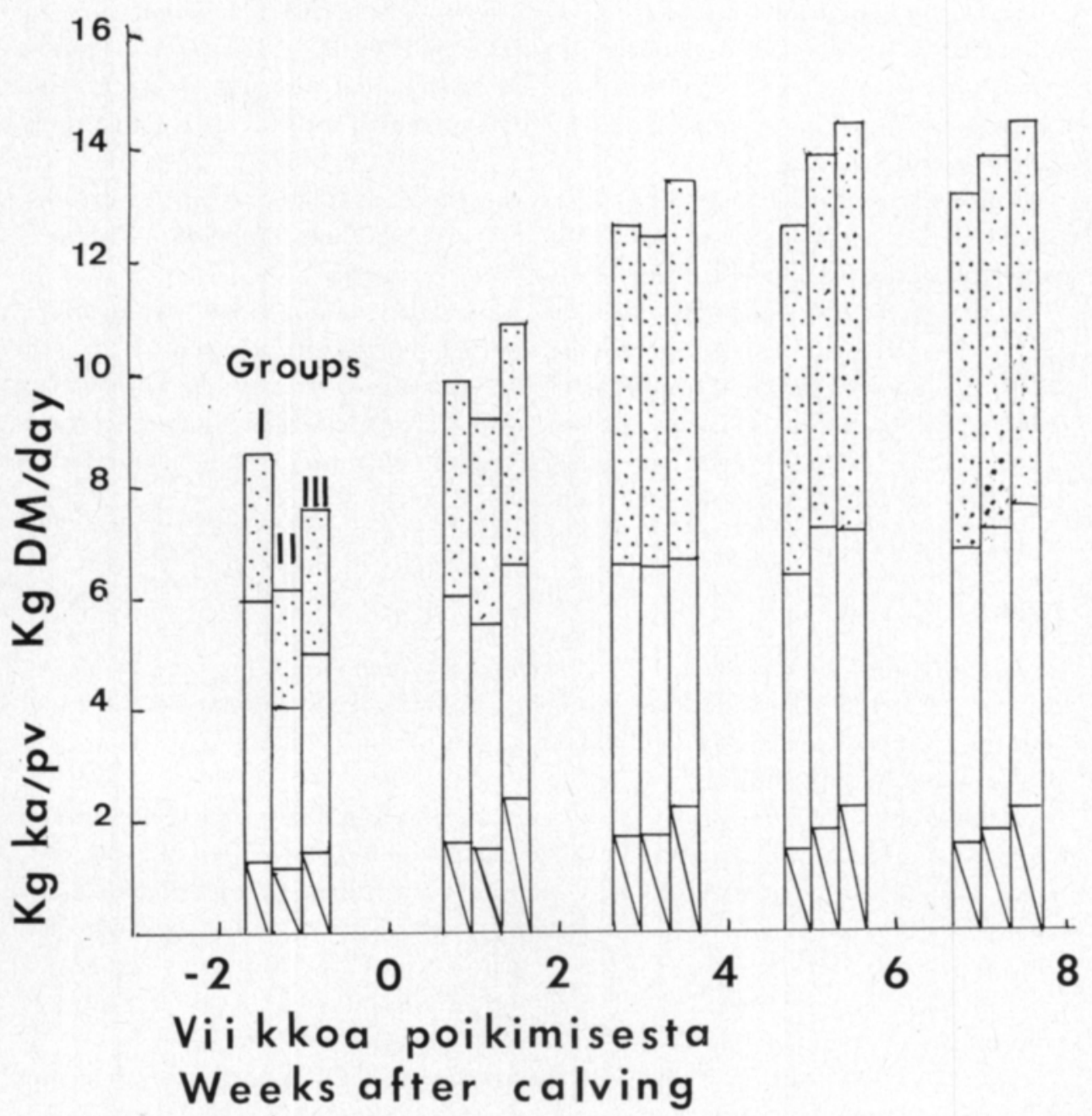

Kuva 1. Kuiva-aineen syönnin kehitys eri ruokintaryhmillä kokeen aikana. (väkirehu $\because$ säilörehu $\square$. heinä $\square$ ).

Fig. 1. The increase in the daily dry matter intake (DM) for the different feeding groups during. the experiment. (concentrate $\because$, grass silage $\square$, hay $\square$ ). 
syönnistä lisääntyi 6 . viikkoon asti, jolloin väkirehun osuus oli $48-50 \%$ kuivaaineen syönnistä (kuva 1).

Pelkistäviä sokereita oli ryhmän I (S) rehuannoksessa $1.9 \%$, ryhmän II (SM) $4.0 \%$ ja ryhmän III (SS) $2.5 \%$ rehuannoksen kuiva-aineesta.

Maitotuotos oli keskimäàrin kokeen aikana ( $0-9$ vk) ryhmällä I (SS) $21.7 \pm$ 4.5 , ryhmällä II (SM) $24.4 \pm 5.1$ ja ryhmällä III (SS) $24.6 \pm 6.5 \mathrm{~kg} 4-\%$ :ista maitoa päivässä (taulukko 3). Laktaatiohuippu saavutettiin ryhmillä I (S) ja III (SS) viidennellä viikolla (23.0 kg ja $26.1 \mathrm{~kg} \mathrm{4- \% :ista} \mathrm{maitoa).} \mathrm{Ryhmän} \mathrm{II}$ (SM) laktaatiohuippu (26.1 kg) osvi neljännelle viikolle poikimisesta (kuva 2). Maidon rasva- ja valkuaispitoisuuksissa ei ollut ryhmien välillä merkitseviä ercja (taulukko 3).

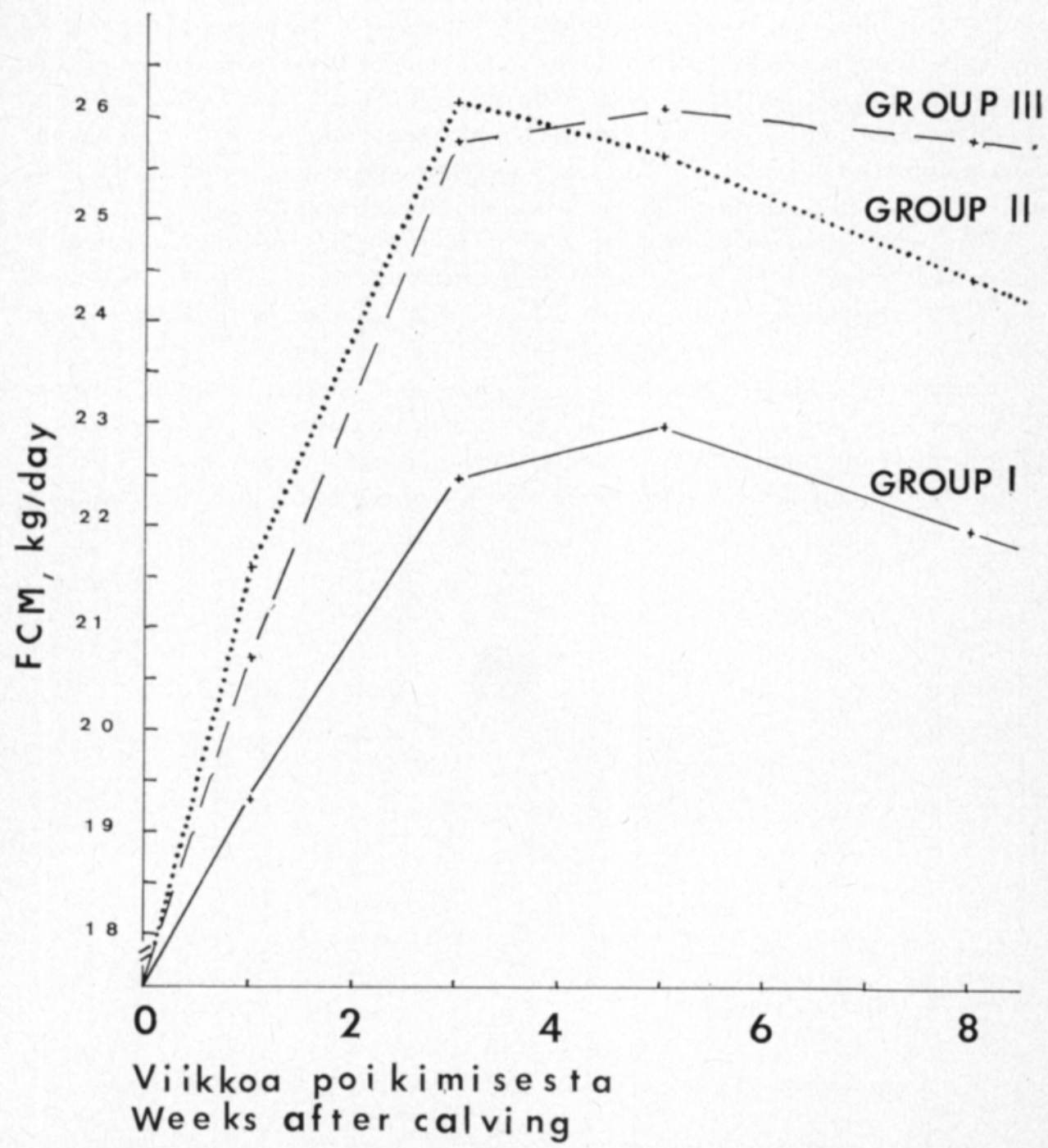

Kuva 2. Päivittäinen maitotuotos eri ruokintaryhmillä kokeen aikana $(0-8$ viikkoa).

Fig. 2. Daily milk yield of the different feeding groups during the experiment ( $0-8$ weeks). 
Taulukko 3. Maitotuotokset ja maidon koostumus eri ryhmillä keskimäärin $0-9$ viikkoa poikimisesta.

Table 3. The mean daily yields and milk composition of the different groups during $0-9$ weeks after calving.

\begin{tabular}{|c|c|c|c|}
\hline & $\begin{array}{l}\text { R y h m } \\
\text { I (S) }\end{array}$ & $\begin{array}{l}\text { Group } \\
\text { II (SM) }\end{array}$ & III (SS) \\
\hline Maitotuotos kg 4-\% FCM - Milk yield & $21.7 \pm 4.5$ & $24.4 \pm 5.1$ & $24.6 \pm 6.5$ \\
\hline Rasva $\%$ - Fat $\%$............................. & $5.0 \pm 0.5$ & $5.1 \pm 0.6$ & $4.7 \pm 0.5$ \\
\hline Valkuais $\%$ - Protein $\%$..................... & $3.8 \pm 0.5$ & $3.6 \pm 0.5$ & $3.6 \pm 0.4$ \\
\hline
\end{tabular}

Ravintoaineiden saanti. Kaikilla ryhmillä oli poikimisen jälkeen energian saannissa vajausta (kuva 3). Ryhmä I (S) sai kokeen aikana rehusta keskimäärin $94 \%$, ryhmä II (SM) $82 \%$ ja ryhmä III (SS) $90 \%$ lasketusta energian tarpeestaan. Energian vajaus oli suurimmillaan kahden ensimmäisen viikon aikana poikimisesta. Tällöin eläimet saivat rehussa keskimäärin vain $71 \%$ lasketusta energiantarpeestaan. Elopainon muutos lehmää kohti oli ensimmäisenä kuukautena poikimisesta ryhmillä I (S) ja II (SM) $0.64 \mathrm{~kg} / \mathrm{pv}$ sekä ryhmällä II (SM) $0.29 \mathrm{~kg} / \mathrm{pv}$. Kokeen loppuaikana elopainon muutokset tasoittuivat.

Typellisten aineiden saanti ylitti normit. Ryhmä I (S) sai keskimäärin sulavaa raakavalkuaista $83 \mathrm{~g}$ per 4-\%:inen maitokilo, ryhmä II (SM) 75 g sekä soijalisän väkirehussa saanut ryhmä III (SS) $89 \mathrm{~g}$ päivässä. Soijarouheen osuus oli keskimäärin $11.4 \%$ :a ryhmän III (SS) valkuaisen saannista.

Kaikilla ryhmillä oli kalsiumin ja magnesiumin puute poikimisen jälkeen. Rehuannoksen kalsium vastasi $70-82 \%$ kalsiumtarpeesta. Kalsiumvajaus johtui säilörehun alhaisesta syönnistä ja kivennäisrehun alhaisesta Ca-pitoisuudesta. $\mathrm{Ca} / \mathrm{P}$-suhde oli $0.8-1.15$. Magnesiumin saanti rehussa poikimisen jälkeen

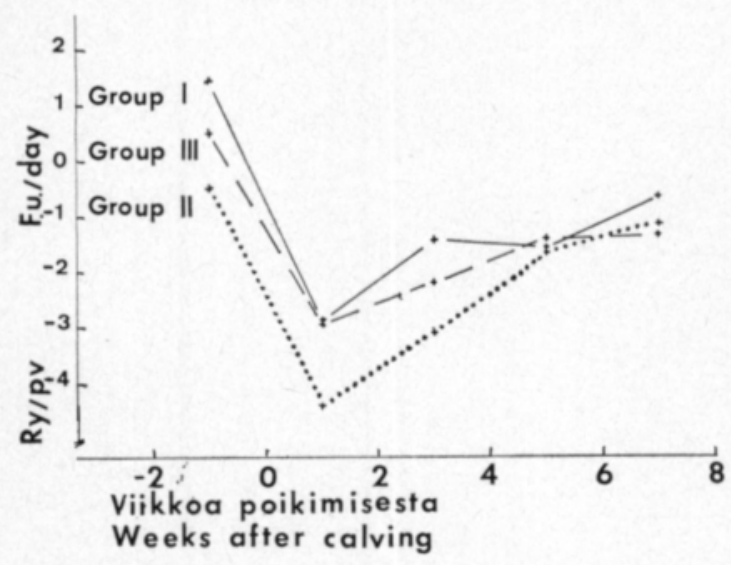

Kuva 3. Laskennallinen energian saannin ja tarpeen erotus eri ruokintaryhmillä. Ryhmä I (S) $x--x$, ryhmä II (SM) $x \ldots . . . x$, ryhmä III (SS) $x---x$. Fig. 3. Estimated difference between energy supply and requirement (f.u./day) for the different feeding groups.

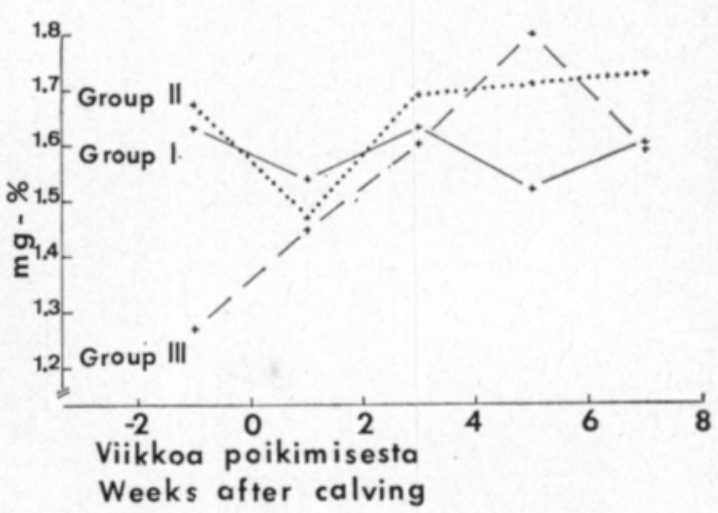

Kuva 4. Plasman Mg-arvojen muutokset eri ruokintaryhmillä kokeen aikana. Ryhmä I (S) $x--x$, ryhmä I (SM) $x \ldots . . . x$, ryhmä I (SS) $x---x$.

Fig. 4. Changes in the magnesium content of plasma for different feeding groups during the experiment. 
vastasi $64-90 \%$ magnesiumin tarpeesta. Nurmisäilörehun alhainen Mg-pitoisuus ja albainen syönti sekä kivennäisrehun alhainen Mg-pitoisuus olivat tärkeimmät syyt magnesiumin vajaukseen. Fosforia ja natriumia lehmät saivat rehussa tarvettaan vastaavasti.

\section{Veriarvojen muutokset}

Veren glukoosi- ja ketoainepitoisuuksissa ei ryhmien välillä ollut tilastollisesti merkitseviä eroja (taulukko 4). Alhaisimmat glukoosiarvot ja korkeimmat ketoarvot keskimäärin kokeen aikana esiintyivät 15-28 päivää poikimisesta. Ketoarvojen ja glukoosiarvojen keskinäinen korrelaatio oli merkitsevä ( $\mathrm{r}=$ $\left.-0.58^{* * *}\right)$. Epäedullisimmat glukoosi- ja ketoarvot esiintyivät ryhmällä I (S) jo 0-14 päivää poikimisesta, kun taas ryhmillä II (SM) ja III (SS) $15-28$ päivää poikimisesta. Veriarvojen perusteella (glukoosi $<40 \mathrm{mg}$ - $\%$. tai ketoarvot $>10 \mathrm{mg}-\%$ ) sairasti ketoosia ryhmissä I (S) ja III (SS) yksi eläin kummassakin. Ryhmässä II (SM) nämä rajat ylitti kolme lehmää. Veren hematokriitti ja hemoglobiiniarvoissa ei ollut ryhmien välillä merkitseviä eroja. Molempien arvot alenivat kokeen kuluessa merkitsevästi $(\mathrm{P}<0.01)$. Alimmat arvot esiintyivät kokeen lopussa.

Plasman kivennäispitoisuudet keskiarvoina on esitetty taulukossa 4. Plasman epäorgaanisen fosforin pitoisuudet olivat ryhmällä II (SM) merkitsevästi $(\mathrm{P}<0.01)$ korkeampia ja kalsiumarvot merkitsevästi $(\mathrm{P}<0.05)$ alhaisempia kuin ryhmillä I (S) ja III (SS). Plasman Ca-arvoihin lisääntyvä maitotuotos herumisvaiheessa ei vaikuttanut, joskin keskiarvot olivat normaaliarvoja (10 mg-\%) alhaisempia. Epäorgaanisen fosforin arvot alenivat merkitsevästi $(\mathrm{P}<0.05)$ poikimisen jälkeen. Alhaisimmat arvot kaikkien lehmien keskiarvona $5.32 \mathrm{mg}-\%$ saavutettiin $28-42$ päivää poikimisesta.

Taulukko 4. Veriarvojen ryhmittäiset keskiarvot koko kokeen aikana.

Table 4. The mean haemotological values of cows during the whole experiment.

\begin{tabular}{|c|c|c|c|c|}
\hline $\begin{array}{l}\text { Ryhmä } \\
\text { Group }\end{array}$ & $\begin{array}{l}\text { Lehmäluku } \\
\text { Number of cows }\end{array}$ & $\begin{array}{l}\text { Hemoglobiini } \\
\text { Haemoglobin }\end{array}$ & $\begin{array}{c}\text { Glukoosi } \\
\text { Glucose } \\
m g-\%\end{array}$ & $\begin{array}{c}\text { Ketoaineet } \\
\text { Ketone bodies } \\
m g-\%\end{array}$ \\
\hline 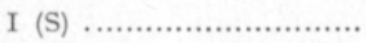 & 5 & $11.4 \pm 1.3$ & $48.7 \pm 7.2$ & $6.6 \pm 3.6$ \\
\hline 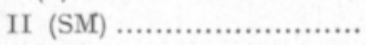 & 6 & $10.9 \pm 1.7$ & $46.5 \pm 5.4$ & $6.5 \pm 3.0$ \\
\hline \multirow[t]{2}{*}{ 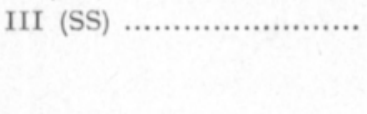 } & 6 & $10.9 \pm 1.0$ & $4.8 \pm 6.1$ & $6.3 \pm 2.1$ \\
\hline & \multicolumn{3}{|c|}{ Plasmassa - In plasma } & \\
\hline Ryhmä & $\mathrm{Ca}$ & inorg. $\mathrm{P}$ & $\mathrm{Mg}$ & $\mathrm{Na}$ \\
\hline Groups & $\mathrm{mg} \cdot \%$ & $\mathrm{mg}-\%$ & $\mathrm{mg}-\%$ & $\mathrm{mg}-\%$ \\
\hline 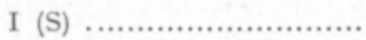 & $9.1 \pm 0.5^{\mathrm{a}}$ & $5.5 \pm 1.0^{\mathrm{e}}$ & $1.6 \pm 0.1$ & $333 \pm 10.2^{\mathrm{ab}}$ \\
\hline II $(\mathrm{SM}) \ldots \ldots \ldots \ldots \ldots \ldots \ldots \ldots \ldots \ldots \ldots \ldots$ & $8.6 \pm 0.5^{b}$ & $6.6 \pm 0.8^{d}$ & $1.7 \pm 0.2$ & $330 \pm 9.3^{b}$ \\
\hline III (SS) $\ldots \ldots \ldots \ldots \ldots \ldots \ldots \ldots$ & $9.0 \pm 0.9^{a}$ & $5.5 \pm 0.9 e$ & $1.5 \pm 0.3$ & $340 \pm 14.1^{\mathrm{a}}$ \\
\hline
\end{tabular}

Merkitsevät erot ruokintaryhmien välillă

Significunt differences between feeding groups $\mathrm{a}-\mathrm{b}: \mathrm{P}<0.05$

$\mathrm{d}-\mathrm{e} ; \mathrm{P}<0.01$ 
Plasman magnesiumpitoisuus jäi kaikilla ryhmillä hypomagnesemian rajana pidetyn $1.80 \mathrm{mg}-\%$ alapuolelle. Alhaisimmat arvot esiintyivät heti poikimisen jälkeen, jolloin kaikkien ryhmien keskiarvo 1.49 mg-\% oli merkitsevästi ( $\mathrm{P}<$ 0.05 ) alhaisempi kuin jaksolla 43-64 päivää poikimisesta 1.65 mg-\% (kuva 4).

\section{Tarkastelu}

Rehun syönnin kehitys poikimisen jälkeen vastasi laktaatiokauden alkuvaiheessa suoritettuja tutkimuksia (WAGNER ja LoosLi 1967, EKERN 1972, WIKTORSSON 1971, 1973).

Väkirehun syönti lisääntyi nopeimmin poikimisen jälkeen. Myös nurmisäilörehun syönti lisääntyi, mutta määrät suurimmillaankin $(5.3 \mathrm{~kg} \mathrm{ka})$ olivat huomattavasti alhaisempia kuin mitä on esitetty pohjoismaisissa tutkimuksissa (EtTal.a ym. 1975, Mo 1974). Alhaiseen säilörehun syöntiin lienee ollut syynä voimakas säilörehun käyminen, jonka seurauksena sokeripitoisuus oli alhainen ja $\mathrm{NH}_{3}-\mathrm{N}$-pitoisuus korkea. Myös etikkahappopitoisuus oli tavallista korkeampi. Kaikkien em. seikkojen on todettu alentavan säilörehun maittavuutta (ETTALA ym. 1975).

Melassileike väkirehussa kohotti 4-\%:ista maitotuotosta keskimäärin 2.7 $\mathrm{kg} / \mathrm{pv}$, joskaan ero ei ollut tilastollisesti merkitsevä eläinaineksen heterogeenisyydestä johtuen. Tämä tulos tukee niitä tutkimuksia, joissa pienellä sokerilisäyksellä on havaittu lievää positiivista vaikutusta maitotuotokseen (HIRoNAKA 1971, SALO ym. 1973). Kokeen päätyttyä lehmien siirtyessä samalle ruokinnalle (20\% melassileikettä väkirehussa), tuotoksien aleneminen kahden seuraavan viikon aikana oli ryhmillä II (SM) ja III (SS) $0.14 \mathrm{~kg}$ ja $0.13 \mathrm{~kg}$ päivässä. Pelkkää ohra-kauraseosta saaneella ryhmällä I (S) tuotos pysyi samana tai pyrki kohoamaan $(\mathrm{b}=+0.05)$.

Sokerilisän on todettu edistävän runsasvalkuaisen nurmisäilörehun typellisten aineiden hyväksikäyttöä märehtijällä tehokkaammin kuin tärkkelys (SYRJÄLÄ 1972). SYRJÄLÄ (1975) totesi sokerilisän parantavan nuorten karitsoiden kasvua tehokkaammin kvin tärkkelyslisä, silloin kun säilörehu on voimakkaasti käynyttä. Tuotoksien yhtäsuuruus ryhmillä II (SM) ja III (SS) osoittaisi melassileikkeen edistäneen valkuaisaineiden saantia yhtä tehokkaasti kuin soijavalkuainen. Varhaisella kasvuasteella korjatusta ja runsaasti typpilannoitetusta nurmesta tehdyllä säilörehulla pystytään turvaamaan korkeatuottoisen lehmän määrällinen valkuaistarve, mutta tämän tutkimuksen mukaan valkuaisen laatu voi muodostua tuotosta rajoittavaksi. Norjassa suoritetussa useampivuotisessa tutkimuksessa (Mo 1974) öljyväkirehulisä paransi merkitsevästi maitotuotosta säilörehuruokinnalla, vaikka valkuaisen annostus jo ilman lisävalkuaista ylitti normit (67 g ja $76 \mathrm{~g}$ per kg 4-\%:sta maitoa). Runsaalla typpilannoituksella kohotettu nurmisäilörehun valkuainen kchotti myös hieman, muttei merkitsevästi maitotuotosta, vaikka valkuaisannostus cli suurempi kuin öljyväkirehulisäyksellä (67 g ja $80 \mathrm{~g}$ srv per kg 4-\%:ista maitoa). Nyös CASTLE ja WATSON (1974) havaitsivat hyvälaatuisen rehuvalkuaisen kohottavan merkitsevästi maitotuotosta apilasäilörehuruokinnalla.

Lehmät saivat kokeen aikana $(0-9 \mathrm{vk})$ rehussa keskimäärin $89 \%$ lasketusta energiantarpeestaan. Maidontuotannon huippu osui $3 \mathbf{- 5}$ viikolle, kun taas re- 
hun syönti oli suurimmillaan kokeen lopussa. Lehmillä energiavajaus heti poikimisen jälkeen on lähes väistämätön tosiasia, mutta tässä kokeessa energiavajaus oli pahempi kuin monissa muissa tutkimuksissa (EKERN 1972, Wiktorson 1971) johtuen säilörehun huonosta maittavuudesta.

Korkeampi rehun sokeripitoisuus ei kohottanut veren glukoosipitoisuutta, mikä oli odotettuakin. Väkirehu-karkearehusuhteella on suurempi merkitys elimistön glukoosin saantiin (ERFLE ym. 1974). Tässä kokeessa väkirehukarkearehusuhde oli lähes sama kaikilla ryhmillä.

Kokeessa kävi ilmi, että myös kivennäisruokinta voi muodostua kriittiseksi tekijäksi laktaatiokauden alussa. Rehun syönnin hidas lisääntyminen, nurmisäilörehun huono maittavuus ja kivennäisrehun alhainen Ca-sisältö olivat syynä poikimisen jälkeiseen kalsiumvajaukseen. Elimistön homeostaattinen mekanismi pystyi kompensoimaan kalsiumin puutoksen, mutta plasman Ca-arvot jäivät normaaliarvojen alapuolelle. Plasman Ca-arvojen on todettu reagoivan vasta pitempiaikaiseen kalsiumvajaukseen (PAYNE ym. 1970).

Magnesiumaineenvaihduntahäiriöt on todettu liittyvän poikimisen jälkeiseen energiavajaukseen (PEHRSON 1963) tai laidunkauden alkuun, jolloin ruokinnan ja olosuhteiden äkillinen muutos alentaa rehunsyöntiä (Kossıla ym. 1972). Norjalaisten tutkimusten mukaan (Hvidsten ja LANGERBREKKE 1972) energiavajaus ei yksistään aiheuta hypomagnesemiaa, ainoastaan korostaa magnesiumin puutosta. Nyt selostettavassa kokeessa plasman Mg-pitoisuus kohosi energian saannin parantuessa. Erikoisesti ryhmän II (SM) plasman Mg-arvot noudattivat eläinten energiatasetta. Tärkein syy hypomagnesemiaan oli magnesiumin puute. Alhainen rehun syönti, säilörehun ja kivennäisrehun alhainen Mg-pitoisuus (1.5\%), aiheuttivat Mg-vajauksen. Säilörehun erittäin korkea $\mathrm{N}$-sisältö erikoisesti $\mathrm{NH}_{3}-\mathrm{N}$ suuri osuus (WILcox ja HofF 1974) ja hieman normaalia korkeampi kaliumpitoisuus (House ja CAMPEN 1971) saattoivat osaltaan alentaa magnesiumin hyväksikäyttöä.

\section{Yhteenveto}

Lypsylehmillä suoritetussa ruokintakokeessa tutkittiin väkirehussa lisätyn melassileikkeen ja soijarouheen vaikutusta rehunkulutukseen, maitotuotokseen, ravintoaineiden saantiin sekä eräisiin veriarvoihin.

Kokeessa oli kolme ruokintaryhmää. Ryhmissä II (SM) ja III (SS) oli 6 lehmää, ryhmässä I (S) 5. Lehmät saivat perusrehuina heinää ja nurmisäilörehua. Väkirehuna ryhmä I (S) sai pelkkää ohra-kauraseosta (50:50). Ryhmä II (SM) sai sokerilisänä melassileikettä $20 \%$ väkirehussa. Tämä kohotti koko rehuannoksen sokeripitoisuutta $1.9 \%$ :ista $4.0 \%$ :iin. Ryhmä III (SS) sai valkuaislisänä väkirehussa $11 \%$ soijarouhetta. Soijarouheen osuus oli $11.4 \%$ ryhmän koko rehuannoksen sulavasta raakavalkuaismäärästä.

Rehun syönti lisääntyi $40 \mathrm{~g} \mathrm{ka/100} \mathrm{elopainokiloa} \mathrm{päivässä} \mathrm{ensimmäisen} \mathrm{kuu-}$ kauden aikana poikimisesta. Rehun syönti kokeen lopussa (8 viikkoa poikimisesta) oli ryhmällä I (S) $2.8 \pm 0.2$, ryhmällä II (SM) $3.0 \pm 0.2$ ja ryhmällä III (SS) $3.0 \pm 0.4 \mathrm{~kg}$ ka per 100 elopainokiloa. Ryhmien välillä ei ollut merkitsevää eroa rehunkulutuksessa. 
Maitotuotos oli keskimäärin kokeen aikana $(0-9$ viikkoa poikimisesta) ryhmällä I (S) $21.7 \pm 4.5$, ryhmällä II (SM) $24.4 \pm 5.1$ ja ryhmällä III (SS) $24.6 \pm 6.5 \mathrm{~kg} \mathrm{4- \% :ista} \mathrm{maitoa} \mathrm{päivässä.} \mathrm{Erot} \mathrm{eivät} \mathrm{olleet} \mathrm{tilastollisesti} \mathrm{merkit-}$ seviä suuresta hajonnasta johtuen.

Kaikilla ryhmillä oli poikimisen jälkeen energian saannissa vajausta. Ryhmä I (S) sai kokeen aikana $94 \%$, ryhmä II (SM) $82 \%$ ja ryhmä III (SS) $90 \%$ lasketusta energian tarpeesta. Sulavaa raakavalkuaista ryhmä I (S) sai keskimäärin $83 \mathrm{~g}$ per 4-\%:inen maitokilo, ryhmä II (SM) $75 \mathrm{~g}$ ja soijalisän saanut ryhmä III (SS) 89 g srv per 4-\%:inen maitokilo.

Lehmät eivät saaneet kalsiumia eivätkä magnesiumia rehussa poikimisen jälkeen tarvettaan vastaavasti. Rehuannoksen kalsium vastasi $70-82 \%$ lehmien kalsiumin tarpeesta. Magnesiumin saanti rehussa oli $64-90 \%$ tarpeesta.

Plasman hemoglobiini-, hematokriitti-, glukoosi- ja ketoainearvoissa ei ryhmien välillä ollut merkitseviä eroja. Hypoglykemiaa (glukoosi $<40 \mathrm{mg}$-\%) esiintyi ryhmissä I (S) ja III (SS) yhdellä lehmällä sekä ryhmällä II (SS) kolmella lehmällä.

Plasman epäorgaanisen fosforin pitoisuudet olivat ryhmällä II (SM) 6.6 mg-\% ja ryhmillä I (S) ja III (SS) 5.5 mg-\%. Erot olivat merkitseviä $(\mathrm{P}<$ 0.01). Plasman kalsiumarvot olivat ryhmällä II (SM) merkitsevästi $(\mathrm{P}<0.05)$ alhaisempia kuin ryhmillä I (S) ja III (SS). Plasman magnesiumarvot olivat hypomagnesemian rajan alapuolella koko kokeen ajan. Ryhmien välillä ei ollut merkitseviä eroja. Plasman magnesiumarvojen muutokset noudattivat lehmien magnesiumin ja energian saantia.

\section{KIRJALLISUUSLUETTELO}

Anos. 1965. The nutrient requirements of farm livestock. No 2. Ruminants. London. BAKKER, N. \& WHITE, R. R. 1957. A simplified micro-method for the colometric determination of total acetone bodies in blood. N. Z. J. Sci. 38: 1001-1008.

BAKKer, S. B. \& SUMmerson, W. H. 1941. The colorimetric determination of lactic acid in biological material. J. Biol. Chem. 138: 535-554.

Castle, M. E. \& Watson, J. N. 1974. Red clover silage for milk production. J. Br. Grassld Soc. $101-108$.

EKERN, A. 1972. Feeding of high yielding dairy cows. III Roughage intake in high yielding cows when fed grass silage ad libitum. Meld. Norg. Landbr. høgsk. 51:32, 30 p.

ERfLe, J. D., Fisher, L. J. \& SAUER, F. D. 1974. Interrelationships between blood metabolites and an evaluation of their use as criteria of energy status of cows in early lactation. Can. J. Anim. Sci: 54:293-303.

Ettala, E., LAmpila, M. \& Rissanen, H. 1976. Väkirehutason vaikutus lehmien säilörehuvaltaisessa ruokinnassa. Kotieläinhoidon tutkimuslaitoksen tiedote 6: 26-44.

- -, Pohjanheimo, O. \& Lampila, M. 1975. Ensilage of grass with acids and acid-formaldehyde additives. II Intake and nutritional value of silages. Ann. Agric. Fenn. 14: $304-318$.

Hironaka, R. 1971. Dried molasses beet pulp in rations of dairy cattle. Can. J. Anim. Sci. 51: $451-455$.

HUIDA, L. 1970. Haihtuvien rasvahappojen kvantitatiivinen määrittäminen pōtsinesteestä säilörehusta kaasu-nestekromatograafisesti. J. Sci. Agr. Soc. Finnl. 45:483-488.

House, W. A. \& CAMpen, D. van. 1971. Magnesium metabolism of sheep fed different levels of potassium and citric acid. J. Nutr. 101: 1483-1492. 
Hvidsten, M. \& LangerbrekKe, A. 1972. Hypomagnesaemia in dairy cattle on stall rations restricted in magnesium and energy. Festskrift til 70. årsdag. Prof. K. Breirem p. 83-97 Oslo-Ås.

Kaufmann, W. \& Hagemeister, H. 1975. Zur Verwertung von Harnstoff (NPN) beim Wiederkäuer. Ùbers. Tierernährg. 3 (1975): 33-65.

Kossila, V., Virtanen, E. \& Ahtiainen, P. 1972. Laidunkauden alussa muutoksia kivennäis- ja hivenaineiden saannissa sekä lehmän veren koostumuksessa. Karjatalous 48 : $210-214$

McCullough, H. 1967. The determination of ammonia in whole blood by a direct colorimetric method. Clin. Chim. Acta 17: 297-309.

Mo, M. 1974. Surfor fra moderat og sterkt gjødslet eng til melkekyr. NJF Grovfodersymposium, Randers. Konsulentavdelningens stencilserie. Husdjur 45: H1-H10.

Nelson, N. 1944. A photometric adaptation of Somogyi method for the determination of glucose. J. Biol. Chem. 153: 375-380.

Payne, J. M., Dew, S. M., Manston, R. \& Faulks, M. 1970. The use of a metabolic profile test in dairy herds. Vet. Rec. 87: 150-158.

PeHrson, B. 1963. Alimentärt betingad hypomagnesemi hos stallfodrade kor. Nord. Vet. Med. 15: $937-976$.

Salo, M.-L. 1965. Determination of carbohydrate fractions in animal foods and faeces. Acta Agr. Fenn. 105: 1-102.

— -, Immonen, M. \& LUomaJÄRVI, U. 1973. Rehuyhdistelmän sokeripitoisuuden vaikutus lehmien maidontuotantoon ja veriarvoihin. J. Sci. Agr. Soc. Finl. 45: 519-527.

SomocyI, M. 1945. A new reagent for the determination of sugars. J. Biol. Chem. 160: $61-68$.

SYRJÄLÄ, L. 1972. Effect of different sucrose, starch and cellulose supplements on the tilization of grass silages by ruminants. Ann. Agric. Fenn. 11: 199-276.

- -1975 . Live-weight gain, feed intake and wool growth of lambs on different grass silage and sucrose and starch supplements. Ann. Agric. Fenn. 14: 338-348.

TAUSSKY, H. H. \& SHORR, E. 1953. A microcolometric method for the determination of inorganic phosphorus. J. Biol. Chem. 202: 675-685.

WAGner, D. G. \& Loosli, J. K. 1967. Studies on the energy requirements of high producing dairy cows. Cornell Univ. Agr. Expt. Sta Mem. 400.

WiктоRson, H. 1971. Input-output relationships in dairy cows. Uppsala.

- - 1973. Comparison of ad libitum restricted feeding of hay and concentrate. Swed. J. Agric. Res. 3: 153-160.

Wrlcox, G. E. \& Hoff, J. E. 1974. Grass tetany. J. Dairy Sci. 57: 1085-1089.

Käsikirjoitus saapunut 30.11.1976 